\title{
Winter food restriction and summer compensation in red deer stags (Cervus elaphus)
}

\author{
By J. M. SUTTIE*, E. D. GOODALL, K. PENNIE AND R. N. B. KAY \\ Physiology Department, Rowett Research Institute, Bucksburn, Aberdeen AB2 9SB
}

(Received 23 September 1982 - Accepted 27 June 1983)

1. Twelve red deer stags (Cervus elaphus) penned individually from weaning were fed on a concentrate diet. Six stags received the diet to appetite throughout the study, and the other six were restricted to $70 \%$ of the intake of the first group during winter and then fed to appetite during summer.

2. The winter-restricted stags showed remarkable compensatory growth during summer. Compared with the unrestricted stags they showed greater food intake, greater daily live-weight gain and increased food conversion efficiency. Nonetheless, they failed to compensate fully for the previous undernutrition.

3. The hind-foot of the restricted stags failed to grow as long as that of the unrestricted stags.

4. Poor winter nutrition, particularly during the first year of life, and subsequent failure to compensate during the short periods of summer plenty, provides an explanation for the small mature size of wild stags in Scotland.

5. Although the winter-restricted stags were less fat both grossly and relative to body-weight than the unrestricted stags, both groups showed the same relationship of level of fatness to empty-body-weight. In both the groups of stags, extensive fat deposition began once they had reached about half their expected mature weight, a much later stage of development and age than in sheep and cattle.

6. The annual cycle of growth and appetite is considered to form part of a complex adaptive system to enhance survival in a harsh seasonal environment followed by a mild seasonal environment. On Scottish hills deer reach a size appropriate to their environment rather than their genetic potential size.

The red deer (Cervus elaphus) has a wide distribution throughout the temperate regions of the world. Stags from different locations show an enormous variation in body-weight (Mitchell et al. 1977). Whitehead (1950) gave live weights of $145-227 \mathrm{~kg}$ for representative English park stags and also quoted record weights of over $300 \mathrm{~kg}$ for English park stags as compared with $127-145 \mathrm{~kg}$ for Scottish Highland stags (Whitehead, 1964). Within Scotland there is much variation in stag body size; the largest $(160 \mathrm{~kg})$ are from Glen Fiddich, the smallest $(100 \mathrm{~kg}$ ) are from Glen Prosen (Staines, 1970, 1978; Michell et al. 1976).

The small size of these Highland deer seems to be an acquired rather than an inherited characteristic. Red deer stags in New Zealand, derived in the past from Scottish stock, may attain weights of $160 \mathrm{~kg}$ at 3 years of age (Moore \& Brown, 1977). Indigenous red deer in the Grizedale Forest in Cumbria, a favourable habitat, are genetically similar to Scottish red deer (Lowe \& Gardiner, 1974) yet the mature body size of stags is about twice that of stags on the Scottish hill (Mitchell et al. 1981). Scottish stag calves raised by hand and given a concentrate diet weighed over $160 \mathrm{~kg}$ at 2 years of age (Blaxter et al. 1974).

Studies of many wild herbivores have shown that these animals have a characteristically lean carcass containing less than $100 \mathrm{~g}$ fat $/ \mathrm{kg}$ body-weight (Ledger, 1968; Blaxter et al. 1974; Drozdz et al. 1975; Weiner, 1977), much less than is found in well-grown domestic animals (Callow, 1947, 1948, 1958; Callow \& Searle, 1956). Moreover, in the dressed carcasses of wild animals, fat is usually deposited only intermuscularly rather than both inter- and intramuscularly as in domestic animals. Fat deposits in wild herbivores have been shown to vary seasonally (Krog et al. 1976; Mitchell et al. 1976) and with age (Blaxter et al. 1974; Robbins et al. 1974).

The main aim of the present study was to test the hypothesis that poor winter nutrition,

* Present address: Invermay Agricultural Research Centre, Private Bag, Mosgiel, New Zealand. 
particularly during the first winter of life, and subsequent failure to compensate fully during the periods of summer plenty, are responsible for the small size of Scottish deer. A subsidiary aim was to investigate the body composition of red deer stags given unrestricted or seasonally-restricted dietary regimens during winter, for 2 or 3 years.

\section{MATERIALS AND METHODS}

Between 7 and 16 June 1977, twelve wild stag calves were captured in Kincardineshire and brought to the Rowett Research Institute. Their date of birth was unknown but assumed to be 7 June. The animals were penned individually in two adjacent rooms, each with a single window. Light intensity, measured $1 \mathrm{~m}$ above the floor at 12.00 hours, varied between $700 \mathrm{~lx}$ on bright days and $160 \mathrm{~lx}$ on dull days. Out-of-doors light intensity always exceeded $2000 \mathrm{~lx}$. Temperature reflected that of the external environment. The calves were bottle-fed a standard ewe-milk substitute (Nutrilamb; Scottish Agricultural Industries Ltd) and then weaned at 9 weeks of age to a pelleted barley diet. This diet contained $869 \mathrm{~g}$ dry matter (DM) $/ \mathrm{kg}$ and provided $15.28 \mathrm{MJ}$ gross energy and $160 \mathrm{~g}$ crude protein (nitrogen $\times 6.25$ ) $/ \mathrm{kg}$ DM.

When 10 weeks old, on 16 August 1977 , the calves were ranked according to live weight and allocated alternately from lightest to heaviest to form two groups. The mean (with SE) live weight of animals in group A was $26 \cdot 2(0.9) \mathrm{kg}$ and in group B $26.9(1.6) \mathrm{kg}$. Group A stags were offered food in excess of their estimated requirements at 08.00 hours. Uneaten food was collected and weighed, and daily food intake thus determined. Group B stags were offered a daily ration that was 0.7 times the mean voluntary intake of group A during the previous week, all food intakes being calculated as $\mathrm{g} \mathrm{DM} / \mathrm{kg}$ body-weight ${ }^{\circ \cdot 75}$. The food restriction continued until May 1978 (Fig. 1) then, over a period of 3 weeks, the feeding levels were adjusted to 80,90 and $100 \%$ of the intake of the unrestricted stags and then increased until the previously-restricted stags were also feeding to appetite. In November 1978 the food restriction was reimposed in group B and continued until May 1979 when the stags were progressively realimented and then fed to appetite as before. The same pattern of feeding was imposed for a third cycle from November 1979 until the study ended in September 1980. Water was freely available at all times.

The stags were weighed at weekly intervals from June 1977 until October 1978 and thereafter at 3-weekly intervals until May 1980 and again in September 1980. At 3-weekly intervals the hind-foot length was measured from the tip of the calcaneum to the junction between the fused metatarsi and the phalanges, using a flexible metal tape.

From February 1978, deer no. 2, a rather intractable animal, had to be sedated by intramuscular injection of Rompun (Bayer; $20 \mathrm{mg} / \mathrm{l}, 1.5 \mathrm{ml} / 100 \mathrm{~kg}$ body-weight) to permit weighing and measuring. Deer nos. 6 and 9 required the same treatment from May and the remaining stags from August 1978. From September 1979 the Rompun was injected by means of a dart rifle (Paxarm Ltd, New Zealand).

Unless otherwise stated, analysis of variance was used to test level of significance $(P<0.05)$.

As far as possible, unrestricted and restricted stags were slaughtered in pairs on the same date. However, this goal was to some extent thwarted by the deaths of four of the twelve experimental animals due to malignant catarrhal fever (W. Corrigall, personal communication).

Subcutaneous, rump (covering the pelvis), abdominal (from the proximal tip of the kidney to the pelvic canal), channel (pelvic canal) and omental (associated with the gut) fat depots were dissected and weighed separately. 


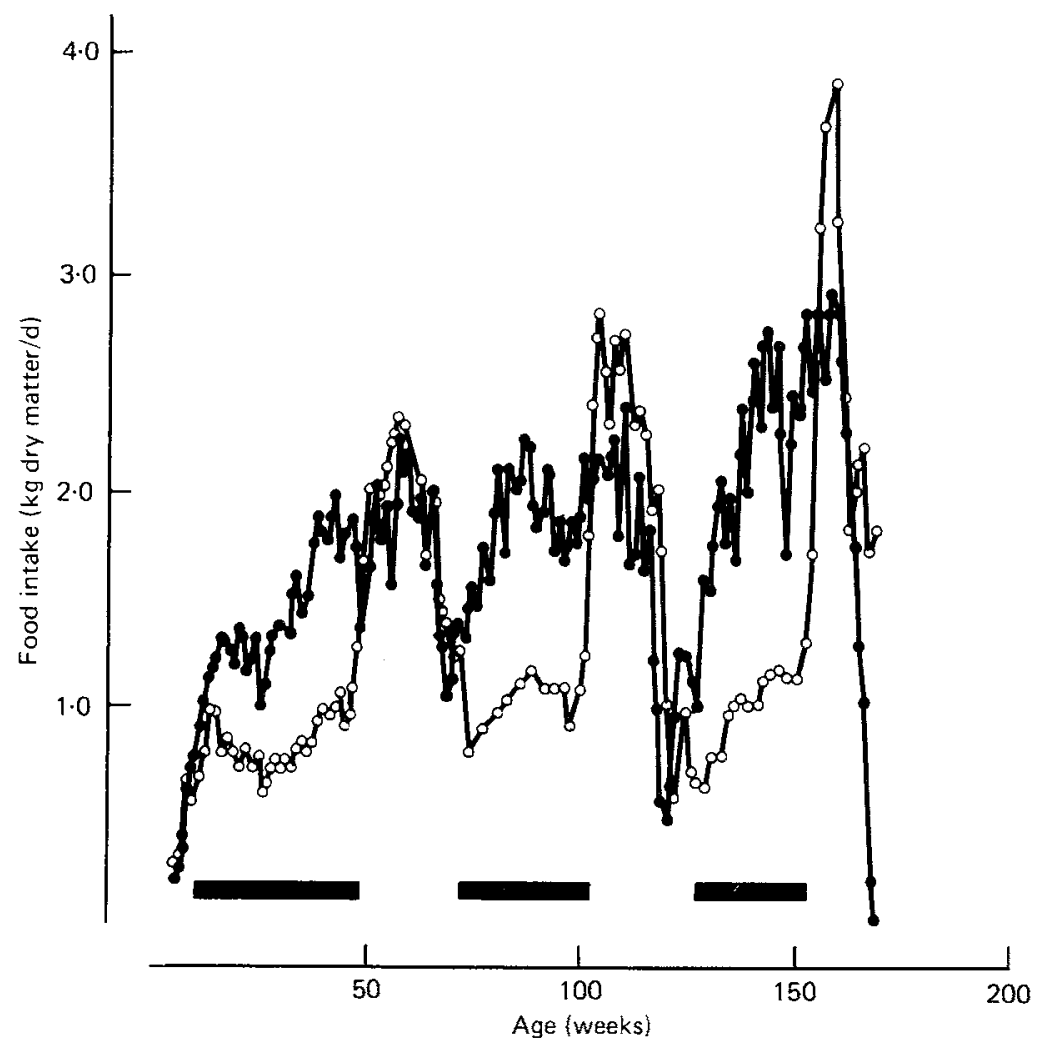

Fig. 1. The food intakes ( $\mathrm{kg}$ dry matter/d) of stags given a concentrated diet at levels of unrestricted (group A) (O) and restricted (group B) (O) intake. (m), Periods of nutritional restriction. Standard errors were smaller than the size of the points.

\section{Chemical analysis}

The empty-body-weight (live weight less gut contents) was divided into four parts for analysis: (1) the left side of the carcass with the channel, rump and all subcutaneous fat removed; (2) all internal organs, channel, abdominal and omental fat, the reproductive tract, the spinal processes and tail; (3) the subcutaneous and rump fat; (4) the head, feet and skin.

Each part was minced through an $8 \mathrm{~mm}$ screen and mixed thoroughly. Three samples, weighing approximately $160 \mathrm{~g}$ each, were taken from the resultant mince and frozen pending freeze-drying. The freeze-dried samples were ground through a $4 \mathrm{~mm}$ screen then stored at room temperature before analysis for dry matter, ash, protein and fat. Dry matter was determined by placing weighed subsamples in an oven at $38^{\circ}$ for $48 \mathrm{~h}$ and then reweighing. The subsamples were then placed in a muffle furnace at $500^{\circ}$ for $24 \mathrm{~h}$ and the ash remaining was weighed. Protein was determined by the method of Davidson et al. (1970) and fat by the method of Atkinson et al. (1972).

\section{RESULTS}

The changes in DM intake are shown in Fig. 1. The daily DM intake of group A, the unrestricted group, increased from weaning until it reached a plateau during the first winter. It rose in spring before falling slightly in May and June. In July and August it was again 




Fig. 2. The live weights (kg) of stags given a concentrated diet at unrestricted (group A) ( $)$ ) and restricted (group B) $(O)$ levels of intake. $(\square)$, Periods of food restriction. Standard errors were smaller than the size of the points.

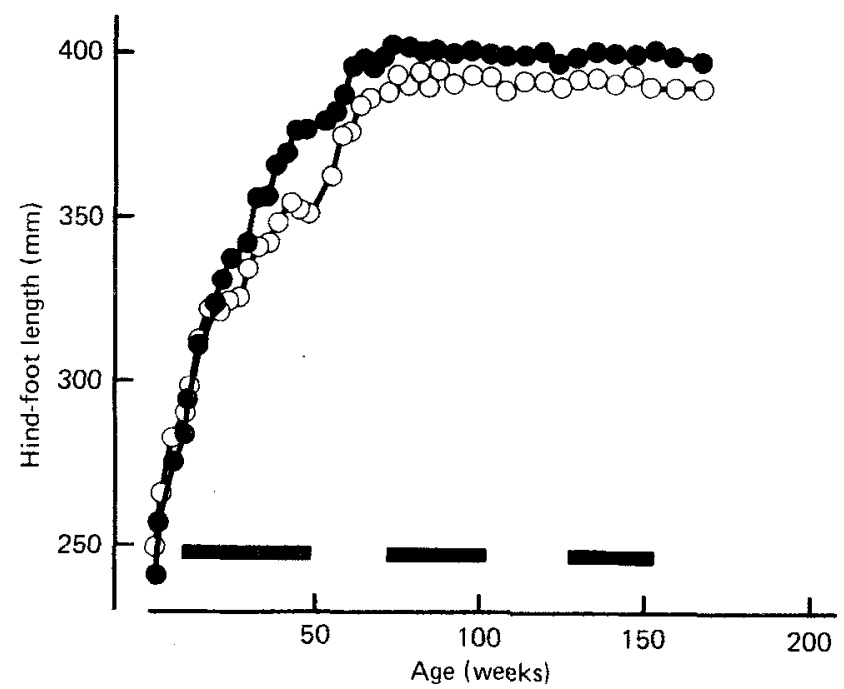

Fig. 3. The hind-foot length (mm) of stags given a concentrated diet at unrestricted (group A) (๑) and restricted (group B) $(O)$ levels of intake. $(\square)$, Periods of food restriction. Standard errors were smaller than the size of the points.

high before it dropped during the rut in October. This pattern was repeated during the second and third years of the study although food intake peaks were higher and troughs lower. The stags in group B raised their DM intake to above that of group A each summer but invariably reduced their intake, voluntarily, in late summer before the rut. Thus they voluntarily curtailed the period of rehabilitation. 
Table 1. Food intake and live weight changes of stags during the summer periods of unrestricted food intake and the winter periods of restricted food intake

(Mean values with pooled estimates of standard errors)

\begin{tabular}{|c|c|c|c|c|c|c|}
\hline & $\begin{array}{c}\text { Group } \\
\text { A } \\
\text { Mean }\end{array}$ & $\begin{array}{c}\text { Group } \\
\text { B } \\
\text { Mean }\end{array}$ & $\begin{array}{l}\text { Pooled } \\
\text { SE }\end{array}$ & $\begin{array}{c}\text { Group } \\
\text { A } \\
\text { Mean }\end{array}$ & $\begin{array}{c}\text { Group } \\
\text { B } \\
\text { Mean }\end{array}$ & $\begin{array}{c}\text { Pooled } \\
\text { SE }\end{array}$ \\
\hline & \multicolumn{3}{|c|}{ Period 1} & \multicolumn{3}{|c|}{ Period 3} \\
\hline DM intake $(\mathrm{kg} / \mathrm{d})$ & 1.52 & $0.83^{* * *}$ & 0.055 & 1.85 & $1.01^{* * *}$ & 0.062 \\
\hline Live wt $(\mathrm{kg})$ & 69.2 & $50 \cdot 5^{* * *}$ & 2.56 & $119 \cdot 2$ & $88 \cdot 9 * * *$ & 3.77 \\
\hline $\begin{array}{l}\text { DM intake (kg/100 kg } \\
\text { metabolic live wt) }\end{array}$ & $6 \cdot 30$ & $4 \cdot 37^{* * *}$ & 0.138 & $5 \cdot 12$ & $3 \cdot 49^{* \bullet *}$ & 0.134 \\
\hline Live-wt gain $(\mathrm{kg} / \mathrm{d})$ & $0 \cdot 21$ & $0 \cdot 11^{* * *}$ & 0.014 & 0.05 & $0 \cdot 01^{* * *}$ & 0.029 \\
\hline \multirow{2}{*}{$\begin{array}{l}\text { Food conversion } \\
\text { efficiency }\end{array}$} & $7 \cdot 31$ & $8 \cdot 11$ & $0 \cdot 641$ & - & values neg & $-\ldots$ \\
\hline & \multicolumn{3}{|c|}{ Period 2} & \multicolumn{3}{|c|}{ Period 4} \\
\hline DM intake $(\mathrm{kg} / \mathrm{d})$ & 1.89 & 2.04 & $0 \cdot 101$ & $2 \cdot 02$ & $2 \cdot 60^{*}$ & $0 \cdot 219$ \\
\hline Live-wt (kg) & $102 \cdot 5$ & $84 \cdot 4^{* * *}$ & $3 \cdot 48$ & $144 \cdot 6$ & $107 \cdot 3^{* * *}$ & $5 \cdot 45$ \\
\hline $\begin{array}{l}\text { DM intake (kg/100 kg } \\
\text { metabolic live wt) }\end{array}$ & 5.88 & $7 \cdot 39 * * *$ & 0.285 & $4 \cdot 86$ & $7 \cdot 73^{* * *}$ & 0.592 \\
\hline Live-wt gain $(\mathrm{kg} / \mathrm{d})$ & $0 \cdot 22$ & $0.30^{*}$ & 0.029 & $0 \cdot 17$ & $0 \cdot 28^{*}$ & 0.038 \\
\hline $\begin{array}{l}\text { Food conversion } \\
\text { efficiency }\end{array}$ & $8 \cdot 882$ & $6 \cdot 84^{*}$ & $0 \cdot 848$ & $12 \cdot 20$ & $9 \cdot 27^{*}$ & $1 \cdot 059$ \\
\hline
\end{tabular}

DM (dry matter) intake is the mean of weekly values; live weight and DM intake/metabolic live weight are mean values estimated for the mid-point of each week; live-weight gain was estimated as a regression coefficient from all weighings during each summer period; food conversion efficiency is the ratio of DM intake (kg): live-weight gain (kg).

Periods 1 and 3 are the periods of restriction from November 1977 until 15 May 1978 ( $n$ 12) and 6 November 1978 until 14 May 1979 ( $n$ 11) respectively. Periods 2 and 4 are the periods of unrestricted food intake from 5 June 1978 until 22 September $1978(n 12)$ and 4 June 1979 until 10 September $1979(n$ 9) respectively. Where $n=11$, SE should be multiplied by 1.044 and where $n=9$ by 1.155 to allow for the fact that there are less than twelve values.

Significance of difference: ${ }^{*} P<0.05,{ }^{* * *} P<0 \cdot 001$.

Fig. 2 shows the changes in live weight for each group. Group A grew well after weaning and showed only a slight weight loss during the rut (weeks 66-69) and a reduced rate of weight gain for 8 weeks following the rut. During the second year of the study they continued to grow but less rapidly than previously and lost about $20 \mathrm{~kg}$ during the second rut and again showed a slight reduction in weight gain after it. During the third year the two remaining stags grew quickly and the last animal attained a maximum individual weight of $189.6 \mathrm{~kg}$ before rut in September 1980 . Group B grew at the same rate as group A until checked by dietary restriction in August 1977. They continued to gain weight, albeit at a slow rate, until realimented in May 1978. Although they grew quickly during the period of realimentation, they did not fully compensate for the previous period of undernutrition, that is, they did not catch up on the weights of group A stags before they voluntarily reduced their food intake in September 1978. During the second period of restriction they lost weight but showed a rapid recovery after food allowance was increased, although as before they failed to exhibit full compensation for previous undernutrition. During the third period of restriction the remaining two stags in group B lost weight and after realimentation, despite a large compensatory increase in food intake, only managed to recover the weight they had lost. 
Table 2. The distribution of dissectable fat in the carcasses of red deer stags given a concentrate diet at unrestricted and restricted levels of intake

\begin{tabular}{|c|c|c|c|c|c|c|c|}
\hline \multirow{2}{*}{$\begin{array}{c}\text { Deer } \\
\text { no. }\end{array}$} & \multirow{2}{*}{$\begin{array}{l}\text { Date of } \\
\text { slaughter }\end{array}$} & \multirow{2}{*}{$\begin{array}{l}\text { Plane of } \\
\text { nutrition }\end{array}$} & \multicolumn{5}{|c|}{ Percentage distribution of total dissectable fat } \\
\hline & & & Abdominal & Channel & Omental & Rump & Subcutaneous \\
\hline 2 & 15 May 1979 & Unrestricted & $15 \cdot 37$ & $3 \cdot 86$ & $23 \cdot 71$ & $11 \cdot 51$ & 45.55 \\
\hline 01 & 9 May 1979 & Restricted & $100 \cdot 00$ & 0 & 0 & 0 & 0 \\
\hline 5 & 11 Sept. 1979 & Unrestricted & $12 \cdot 22$ & 5.84 & $37 \cdot 28$ & $10 \cdot 34$ & $34 \cdot 32$ \\
\hline 9 & 9 Sept. 1979 & Restricted & 15.96 & 8.73 & $33 \cdot 03$ & $8 \cdot 27$ & $34 \cdot 01$ \\
\hline 02 & 13 Nov. 1979 & Restricted & 15.69 & $3 \cdot 30$ & $29 \cdot 27$ & $5 \cdot 26$ & $46 \cdot 48$ \\
\hline 3 & 6 May 1980 & Unrestricted & 17.50 & $2 \cdot 46$ & $38 \cdot 03$ & 8.76 & $33 \cdot 18$ \\
\hline 4 & 9 Sept. 1980 & Unrestricted & $10 \cdot 28$ & 3.61 & $46 \cdot 61$ & $7 \cdot 30$ & $32 \cdot 20$ \\
\hline 00 & 9 Sept. 1980 & Restricted & 11.26 & $7 \cdot 14$ & $36 \cdot 85$ & 6.54 & 38.25 \\
\hline
\end{tabular}

Table 3. Gradients and intercepts of regression equations relating carcass composition to age $(\mathrm{x})$ where $\mathrm{y}=\mathrm{ax}+\mathrm{b}$ for carcass constituents for two groups of stags (three animals per group) given a concentrated diet at unrestricted (group A) and restricted (group B) levels of intake

\begin{tabular}{|c|c|c|c|c|c|}
\hline Carcass constituent $(y)$ & Component & Group & $a$ & $b$ & $y$ at $x=30$ months \\
\hline $\begin{array}{l}\text { Carcass less } \\
\text { subcutaneous fat }\end{array}$ & $\begin{array}{l}\text { Water } \\
\text { Protein } \\
\text { Fat } \\
\text { Ash }\end{array}$ & $\begin{array}{l}\text { A } \\
\text { B } \\
\text { A } \\
\text { B } \\
\text { A } \\
\text { B } \\
\text { A } \\
\text { B }\end{array}$ & $\begin{array}{r}-1.214 \\
-4.792 \\
-0.431 \\
-0.663 \\
3.470 \\
5.220 \\
-1.820 \\
0.241\end{array}$ & $\begin{array}{r}656 \cdot 427 \\
792 \cdot 038 \\
237 \cdot 346 \\
237 \cdot 782 \\
-11 \cdot 349 \\
-88 \cdot 800 \\
117 \cdot 000 \\
58 \cdot 707\end{array}$ & $\begin{array}{r}620 \\
648 \\
224 \\
218 \\
93 \\
68 \\
62 \\
66\end{array}$ \\
\hline Internal organs & $\begin{array}{l}\text { Water } \\
\text { Protein } \\
\text { Fat } \\
\text { Ash }\end{array}$ & $\begin{array}{l}\text { A } \\
\text { B } \\
\text { A } \\
\text { B } \\
\text { A } \\
\text { B } \\
\text { A } \\
\text { B }\end{array}$ & $\begin{array}{r}-9.991 \\
-9 \cdot 272 \\
-3 \cdot 194 \\
-2.362 \\
13.817 \\
11 \cdot 795 \\
-0.264 \\
-0.354\end{array}$ & $\begin{array}{c}821 \cdot 143 \\
932.94 \\
225 \cdot 229 \\
229.292 \\
-80.513 \\
-175.224 \\
16.778 \\
22.031\end{array}$ & $\begin{array}{r}521 \\
655 \\
129 \\
158 \\
334 \\
178 \\
9 \\
11\end{array}$ \\
\hline $\begin{array}{l}\text { Subcutaneous and } \\
\text { rump fat }\end{array}$ & $\begin{array}{l}\text { Water } \\
\text { Protein } \\
\text { Fat } \\
\text { Ash }\end{array}$ & $\begin{array}{l}\text { A } \\
\text { B } \\
\text { A } \\
\text { B } \\
\text { A } \\
\text { B } \\
\text { A } \\
\text { B }\end{array}$ & $\begin{array}{r}-1.419 \\
2.442 \\
-1.578 \\
0.475 \\
3.236 \\
-2.900 \\
0.062 \\
0.017\end{array}$ & $\begin{array}{r}169 \cdot 304 \\
66 \cdot 375 \\
101 \cdot 011 \\
33 \cdot 175 \\
721 \cdot 278 \\
897 \cdot 500 \\
4 \cdot 092 \\
2 \cdot 950\end{array}$ & $\begin{array}{r}127 \\
139 \\
54 \\
47 \\
818 \\
810 \\
2 \\
2\end{array}$ \\
\hline $\begin{array}{l}\text { Head, feet } \\
\text { and skin }\end{array}$ & $\begin{array}{l}\text { Water } \\
\text { Protein } \\
\text { Fat } \\
\text { Ash }\end{array}$ & $\begin{array}{l}\text { A } \\
\text { B } \\
\text { A } \\
\text { B } \\
\text { A } \\
\text { B } \\
\text { A } \\
\text { B }\end{array}$ & $\begin{array}{r}0.556 \\
-4.099 \\
0.156 \\
0.088 \\
0.020 \\
0.237 \\
-0.192 \\
0.084\end{array}$ & $\begin{array}{r}537.479 \\
679 \cdot 504 \\
28.932 \\
30.572 \\
5.351 \\
3.074 \\
11.951 \\
4.551\end{array}$ & $\begin{array}{r}576 \\
556 \\
34 \\
53 \\
6 \\
4 \\
6 \\
7\end{array}$ \\
\hline
\end{tabular}

The stags were slaughtered at 23, 27 and 39 months of age. Data were analysed within groups across time intervals. Predictions of composition of $\mathrm{g} / \mathrm{kg}$ of component weight are given for a standardized slaughter time of 30 months. 


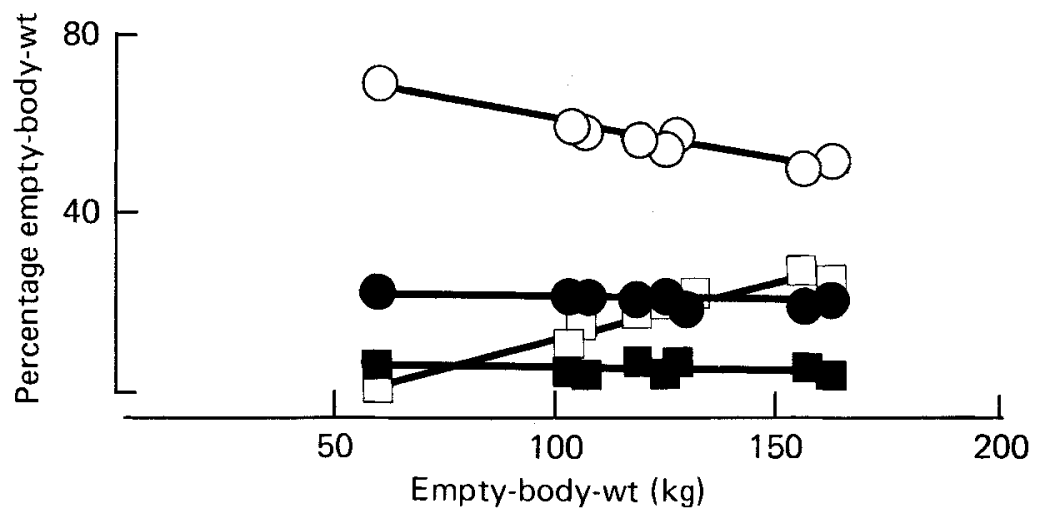

Fig. 4. The relationship between empty-body-weight (live weight less gut contents) and contents of water $(O)$, protein (O), fat ( $\square$ ) and ash (D) in empty-body-weight in red deer stags given a concentrate diet. The linear regression equations for protein, water, fat and ash with correlation coefficients and levels of significance are:

$$
\begin{aligned}
& \text { Fat: } y=0.224 x-10.61, r 0.961, P<0.001 \\
& \text { Protein: } y=-0.03 x-25.09, r 0.784, P<0.05 \\
& \text { Water: } y=-0.166 x+77.728, r 0.955, P<0.001 \\
& \text { Ash: } y=0.022 x+7.788, r 0.713, P<0.05
\end{aligned}
$$

where $y$ is the carcass constituent and $x$ is the age of the stag (months).

The changes in hind-foot length are shown in Fig. 3. In group A the feet grew quickly from birth onwards until an asymptote was reached at 70-75 weeks. In group B there was a period of slow or arrested growth between weeks $40-48$, towards the end of the first period of food restriction. After realimentation foot length increased quickly to reach an asymptote at the same time as in group A (70-75 weeks). Group B did not fully catch up with group $\mathrm{A}$, however, and the means of each group were significantly different $(P<0 \cdot 05, t 2 \cdot 57, n 5$, unpaired two-tailed $t$ test) at this time. After the asymptote was reached no further growth was seen in individual stags even during the second and third periods of realimentation, although the mean values were affected by successive removal of animals from the groups.

Table 1 compares food intake, body-weight change and food conversion efficiency during the first two periods of winter restriction and the first two summers of unrestricted food intake. Although the previously restricted stags of group B ate more than the stags of group $A$ in absolute terms, this only achieved statistical significance during the second period. However, since group B stags were significantly lighter than group A stags, their food intake on a metabolic body-weight basis was substantially and significantly greater in both periods. Group B converted food to weight gain significantly more efficiently than group A in both summer periods but in both groups conversion efficiency was poorer during the second period.

During both periods of food restriction the group A stags were larger and consumed more food than group B stags and during the first winter period gained significantly more weight. There were no significant differences in food conversion efficiency during the first winter and no effect was measurable during the second year as weight gains were low or absent.

The relative distribution and importance of the different fat depots is shown in Table 2. The major fat depots were subcutaneous and omental. Within slaughter pairs, and generally as the stags became older and heavier, the omental depot became larger relative to the subcutaneous depot.

Table 3 shows regression equations for the composition of parts of the empty body with 


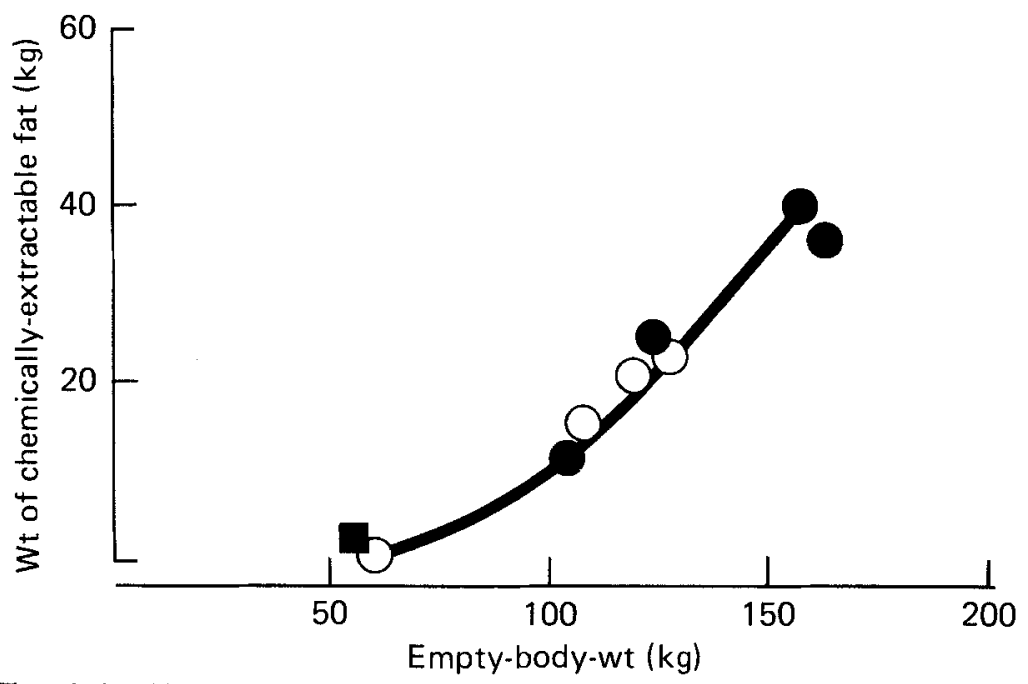

Fig. 5. The relationship between empty-body-weight (live weight less gut contents) and the total fat content of the body, determined chemically, in red deer stags given a concentrated diet at unrestricted (O) or restricted $(O)$ levels of intake. ( $\square$ ), Young farm stags (Kay et al. 1981).

age. The composition of the lean carcass showed a trend towards an increase in fat and a decrease in water as the stags become older and heavier. Protein and ash contents remained relatively constant throughout the study. The previously described pattern was consistent for the composition of internal organs and of the subcutaneous fat, but the composition of the head, feet and skin varied little within pairs or with age.

The percentage composition of the total body (excluding gut contents) of water, protein, fat and ash is illustrated in Fig. 4. As empty-body-weight increased the fat content increased, water decreased and the protein and ash remained about the same. The relationship between the weight of chemically-extractable fat and the empty-body-weight is given in Fig. 5. This shows that the fat content of the body was closely related to body-weight, above a certain threshold, and so with the differing planes of nutrition fat content was largely independent of time of slaughter and age. The lean stags analysed by Kay et al. (1981) fit the curve drawn for the stags in the present study.

\section{DISCUSSION}

The stags on the unrestricted plane of nutrition, group A, showed a pronounced annual cycle of voluntary food intake. This is in agreement with other studies on male deer, caribou (Rangifer tarandus) (McEwan, 1968; McEwan \& Whitehead, 1970), roe-deer (Capreolus capreolus) (Drozdz \& Osiecki, 1973; Drozdz, 1979) and red deer (Simpson, 1976; Kay, 1979). Bandy et al. (1970), in addition to showing a seasonal pattern of food intake in male black-tailed deer (Odocoileus hemionus columbianus), found that there were two phases of inappetence. The first deep trough was associated with the rut but this was followed by a short recovery phase and then a shallow trough in the winter before intake levels rose to the summer peak. The second shallow trough coincided with the female inappetent phase and it was concluded that this was the basic cycle and the male superimposed an additional inappetent phase due to the rut, not shown by the female. In the present study the intake of unrestricted stags increased sharply after the rut and continued to rise until spring when an inappetent phase occurred. Thus in one annual cycle two peaks of food intake occurred, one in early spring, the other in summer. The early spring peak was associated with a 
resurgence of sexual activity, as indicated by increased testis size, a rise in testosterone and a fall in prolactin, that like inappetence was conspicuous in some, mainly group A stags, and absent in others. This subject is considered more fully by Suttie $(1980,1981)$.

The growth of the stags in group A was good in comparison with published accounts. At 27 months old they were approximately twice the weight of stags of similar age at Glensaugh (Blaxter et al. 1974) and they were also heavier than 27-month-old wild stags from Glenfeshie (Mitchell et al. 1977). They were equivalent in weight to stags fed to appetite at the Rowett Research Institute (Blaxter et al. 1974) and in New Zealand (Moore \& Brown, 1977). Group B stags grew better in the first year of life than wild Scottish calves (Mitchell et al 1977) or farmed calves (Blaxter et al. 1974), but clearly showed exaggerated cycles of weight loss and gain caused by the nutritional regimen. Compensatory growth from May to November, although remarkable, did not allow group B to catch up completely with group A during any phase of realimentation. It is concluded that although the winterrestricted stags of group B were larger than their wild counterparts, the nutritional regimen imposed indeed prevented the stags reaching their genetic potential weight.

The hind-foot continued to grow from birth until an asymptote was reached at the same age, about 17 months, in both groups despite the significant body-weight difference. The restricted group B stags continued to increase the length of the hind-foot through most of the first period of undernutrition; this is in agreement with Blaxter et al. (1974) and Mitchell et al. (1976) who showed that farmed and wild stags respectively continued to grow skeletally throughout their first winter. However, skeletal growth rate of group B stags was less during the restricted period than that of the unrestricted group A stags and, despite increased skeletal growth rate during realimentation, the difference was never made up and by the time growth ceased their legs were significantly shorter.

Previous studies on compensatory growth of white-tailed deer (O. virginianus) (French et al. 1956; McEwen et al. 1957; Long et al. 1959; Cowan \& Long, 1962) did not involve repeated periods of nutritional restriction. The present study showed that repeated severe nutritional deprivation has profound deleterious effects on body and skeletal growth.

Over the range of body-weights obtained, the percentage of fat and water varied reciprocally while protein and ash remained more or less constant in the carcass, internal organs and subcutaneous fat. Within the slaughter pairs the restricted stags always had a higher proportion of water to fat, an effect previously noted by Drew \& Reid (1975). The values for the percentage of fat in the carcass were similar to those quoted by Blaxter $e t a l$. (1974) of $9.5-15 \%$ of the carcass for stags fed on dried-grass or concentrates indoor. This contrasts sharply with the values obtained for wild hinds $(2 \cdot 7-8.7 \%)$ and domestic red deer calves $(1 \cdot 3-7 \cdot 8 \%)$ in the same report.

The trend for water content to decrease and fat to increase as empty-body-weight increases is shown graphically in Fig. 4. Robbins et al. (1974) showed that while the amount of protein remained at around $200 \mathrm{~g} / \mathrm{kg}$ and ash at $60 \mathrm{~g} / \mathrm{kg}$, water fell from 750 to $550 \mathrm{~g} / \mathrm{kg}$ and fat rose from 0 to $20 \mathrm{~g} / \mathrm{kg}$ in the empty bodies of male and female white-tailed deer as weight increased from 4 to $68 \mathrm{~kg}$. Almost exactly the same relationship was found in the present study for red deer. The composition of red deer is also within the normal ranges for domestic sheep, cattle and pigs (Berg \& Butterfield, 1976).

It is an apparent paradox that the relationship between percentage body fat and empty-body-weight is linear but the relationship between the weight of chemicallyextractable fat and empty-body-weight is curvilinear. This may be resolved because although stags become relatively fatter as they get older, hence the curvilinearity, at any given body-weight laying down of fat displaces water linearly, hence the percentage fat content is linearly related to empty-body-weight.

The relationship between the weight of chemically-extractable fat and empty-body-weight 
(Fig. 2) closely resembles those reviewed by Searle (1977) for sheep, cattle and rats. The main difference between deer and other ruminants is the intercept on the $x$-axis; deer only begin to deposit substantial amounts of body fat above $85-90 \mathrm{~kg}$ body-weight, about half their mature size, whereas sheep and cattle begin to fatten at lower body-weights and at an earlier stage of development. However, above this intercept, body-weight is the major indicator of fatness in deer as in sheep or cattle. Deer may only be attractively lean animals at low body-weight; at high body-weight they may become as fat as cattle.

The present study emphasizes an important phenomenon; that deer are adaptable in reaching the maximum size their environment can maintain, thus approaching as closely as possible the genetic potential size within the contraints of the environment. The animal appears to be physiologically programmed to deal with periods of inadequate nutrition and to follow them with periods of compensatory growth.

The authors wish to thank Mr S. J. Miller for technical assistance and Mr J. McIntosh for care of experimental animals. Mr I. McDonald gave excellent statistical advice. J.M.S. was in receipt of an NERC post-graduate studentship.

\section{REFERENCES}

Atkinson, T., Fowler, V. R., Garton, G. A. \& Lough, A. K. (1972). Analyst, London 97, 562-568.

Bandy, P. J., Cowan, I. Mct \& Wood, A. J. (1970). Canadian Journal of Zoology 48, 1401-1410.

Berg, R. T. \& Butterfield, R. M. (1976). New Concepts of Cattle Growth. Sydney: Sydney University Press.

Blaxter, K. L., Kay, R. N. B., Sharman, G. A. M., Cunningham, J. M. M. \& Hamilton, W. J. (1974). Farming the Red Deer. Edinburgh: H.M. Stationery Office.

Callow, E. H. (1947). Journal of Agricultural Science, Cambridge 37, 113-131.

Callow, E. H. (1948). Journal of Agricultural Science, Cambridge 38, 174-199.

Callow, E. H. (1958). Journal of Agricultural Science, Cambridge 51, 361-369.

Callow, E. H. \& Searle, S. R. (1956). Journal of Agricultural Science, Cambridge 48, 61-73.

Cowan, R. L. \& Long, T. A. (1962). Pennsylvanian Cooperative Wildlife Research Unit Progress Report no. 107.

Davidson, J., Mathieson, J. \& Boyne, A. W. (1970). Analyst, London 95, 181-193.

Drew, K. R. \& Reid, J. T. (1975). Journal of Agricultural Science, Cambridge 85, 193-204.

Drozdz, A. (1979). Acta Theriologica 24, 137-170.

Drozdz, A. \& Osiecki, A. (1973). Acta Theriologica 18, 81-91.

Drozdz, A. \& Weiner, J., Gebczynska, Z. \& Krasinska, M. (1975). Polish Ecological Studies 1, 85-101.

French, C. E., McEwen, L. C., Magruder, N. D., Ingram, R. N. \& Swift, R. W. (1956). Journal of Wildlife Management 20, 221-232.

Kay, R. N. B. (1979). ARC Research Review 5, 13-15.

Kay, R. N. B., Sharman, G. A. M., Hamilton, W. J., Goodall, E. D., Pennie, K. \& Couts, A. G. P. (1981). Journal of Agricultural Science, Cambridge 96, 79-87.

Krog, J., Wika, M., Lund-Larsen, T., Nordfjell, J. \& Myrnes, I. (1976). Norwegian Journal of Zoology 24, 407-417.

Ledger, H. P. (1968). Symposium of the Zoological Society of London 21, 289-310.

Long, T. A., Cowan, R. L., Wolfe, C. W., Rader, T.\& Swift, R. W. (1959). Pennsylvanian Agricultural Experimental Station Progress Report, no. 209.

Lowe, V. P. W. \& Gardiner, A. S. (1974). Journal of Zoology (London) 174, 185-201.

McEwan, E. H. (1968). Canadian Journal of Zoology 46, 1023-1029.

McEwan, E. H. \& Whitehead, P. E. (1970). Canadian Journal of Zoology 48, 905-913.

McEwen, L. C., French, C. E., Magruder, N. D., Swift, R. W. \& Ingram, R. H. (1957). Transactions of the 22nd North American Wildlife Conference, pp. 119-132.

Mitchell, B., Grant, W. \& Cubby, J. (1981). Journal of Zoology (London) 194, 279-284.

Mitchell, B., McCowan, D. \& Nicholson, I. A. (1976). Journal of Zoology (London) 171, 141-152.

Mitchell, B., Staines, B. W. \& Welch, R. (1977). Ecology of Red Deer. Cambridge: I. T.E.

Moore, G. M. \& Brown, C. G. (1977). New Zealand Journal of Agricultural Science 11, 175-178.

Robbins, C. T., Moen, A. N. \& Reid, J. T. (1974). Journal of Animal Science 38, 871-876.

Searle, T. W. (1977). Proceedings of the Nutrition Society of Australia 2, 53-60.

Simpson, A. M. (1976). A study of the energy metabolism and seasonal cycles of captive red deer. PhD Thesis, University of Aberdeen.

Staines, B. W. (1970). The management and dispersion of a red deer population in Glen Dye, Kincardineshire. $\mathrm{PhD}$ Thesis, University of Aberdeen.

Staines, B. W. (1978). Journal of Zoology (London) 184, 403-419. 
Suttie, J. M. (1980). Proceedings of the 2nd International Reindeer/Caribou Symposium, pp. 341-349.

Suttie, J. M. (1981). The influence of nutrition and photoperiod on the growth, development and endocrine status of captive red deer and Soay Rams. PhD Thesis, University of Aberdeen.

Weiner, J. (1977). Acta Theriologica 22, 3-24.

Whitehead, G. K. (1950). Deer and Their Management in the Deer Parks of Great Britain and Ireland. London: Country Life Ltd.

Whitehead, G. K. (1964). The Deer of Great Britain and Ireland. London: Routledge and Kegan Paul. 